\title{
Optimization and control of working parameters of hot blast furnace
}

\author{
Heng Wang ${ }^{1}$, Shukun Cao ${ }^{1 *}$, QuanchengDong ${ }^{1}$, Yi Cui ${ }^{1}$, Zijian $\mathrm{Cao}^{1}$, Shuqiang Xu ${ }^{1}$ Xiangwen Song ${ }^{1}$, Hao Shen $^{1}$ \\ 1336 West Road Jinan, School of Mechanical Engineering, University of Jinan, Jinan 250022, Shandong Province, China
}

\begin{abstract}
In order to improve the working efficiency of hot blast stoves, reduce environmental pollution, reduce labor intensity and improve combustion efficiency, this paper uses ANSYS software to simulate the temperature field and flow field of the hot blast stove, and uses the PID controller to realize the automatic control of the hot blast stove. The model and working principle of the hot blast stove are briefly introduced. The operating parameters (blowing fan air flow, coal intake) of the hot blast stove are briefly studied. The results show that the amount of air flow of the blast furnace depends on the coal intake of the hot blast stove, which is generally per kilogram of coal. $8 \mathrm{~m}^{3}-10 \mathrm{~m}^{3}$ - air is required. When the coal intake is $120 \mathrm{~kg} / \mathrm{h}$ and the air volume of the blower is $1200 \mathrm{~m}^{3} / \mathrm{h}$, the hot blast stove can work stably with high efficiency. The results obtained are input into the database for later combustion. The work provides a theoretical basis.
\end{abstract}

\section{1 introduction}

The hot blast stove is a device used in the technological process of using fuel combustion to generate flue gas and heat exchange with air to generate hot air for fire heating or industrial breeding, drying or thermal curing ${ }^{[1]}$. How to control the combustion ratio of gas, air and dynamically manage its mixing volume is a crucial task in determining the combustion of hot blast stoves ${ }^{[2]}$. At present, most of the domestic hot blast stoves use coal as their fuel. Most of them use fire bed combustion ${ }^{[3]}$. There are some problems in the traditional combustion control process of hot blast stoves. They rely mainly on the experience of the workers to control the feed rate of the furnace and the air volume of the fans. The inaccurate theoretical basis ${ }^{[4]}$, such as complexity and delay in adjustment, will inevitably lead to low fuel efficiency, increased labor intensity and waste of energy.

This paper analyzes the temperature field of hot air furnace through ANSYS. When the user needs a certain outlet temperature, it determines the operating parameters of the hot stove under the temperature, and controls the flue gas flow and air flow through the design of the PID controller of the hot air furnace device. The combustion ratio of the flue gas flow and air air flow has positive scientific meaning for improving work efficiency, reducing energy consumption, and reducing the labor volume of workers.

\section{Hot air furnace working mechanism.}

In this article, coal is used as the heat source in the hot blast stove, and the coal is sent to the combustion chamber of the hot blast stove for combustion by the grate. The combustion of the fuel produces smoke. The air introduced by the blower is exchanged with the air introduced by the blower in the heat exchange room through the change of the induced draft fan. The speed of the grate and the volume of the exhaust fan regulate the temperature of the flue gas and the flow of air. The PID controller of the stove control system controls the flue gas and the air flow control valve to generate the hot air required by the user ${ }^{[5]}$.

\section{Hot stove physical model modeling, simulation parameter settings.}

\subsection{Hot air furnace physical model modeling}

The model of this paper is based on the physical design of the hot blast stove jointly designed by Shandong Banghua Energy Environmental Engineering Co., Ltd. and Jinan University. The three-dimensional map of the hot blast furnace is shown in Fig. 1. This article focuses on the temperature field of the hot blast stove for ease of simulation and improvement. Efficiency, the establishment of the model is only taking into account the size of the actual work part, regardless of other factors, the simulation modeling ignores the motor, fan, coal-fired machine, grate. Supporting devices and other structures, the simplified hot stove has a combustion chamber and an exchange chamber. The simplified model meshing effect is shown in Fig 2. 


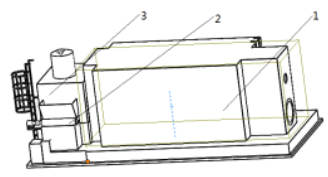

Fig. 1 Three-dimensional view of hot blast stove

1. Heat exchange chamber 2. Grate 3. Combustion chamber

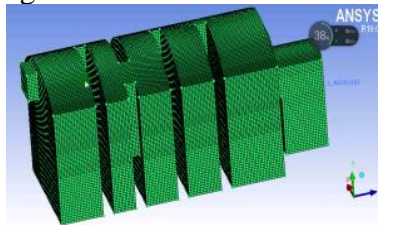

Fig.2 Effect of grid division of hot stove

\subsection{Simulation parameter setting.}

In the analysis process, the actual analysis part of the hot blast stove is meshed. The mesh size is shown in Fig. 3a. The ANSYS software needs to set some parameters in the hot blast stove. The energy problem is involved in the hot blast stove model and the existence of voids needs to consider the influence of turbulence. Therefore, the standard $\mathrm{K}-\omega$ model of our turbulence model is shown in Figure $3 \mathrm{~b}$, and the solution control parameter panel is shown in Figure 3c. 3d shown. This paper mainly studies the temperature field and flow field of the hot blast stove, so set the material property parameters related to temperature and flow. The attribute parameters of the materials are shown in Table 1, Table 2, and Table 3, and the technical parameters of the hot blast stove are shown in Table 4.

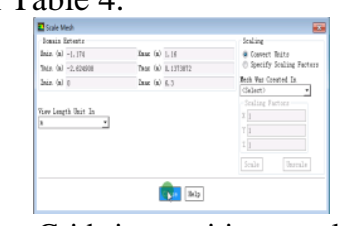

a Grid size partition panel.

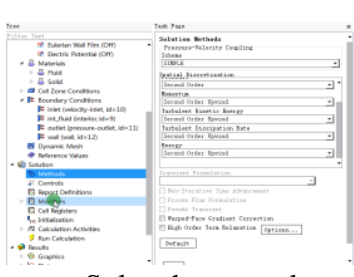

c Solve the control parameter panel.

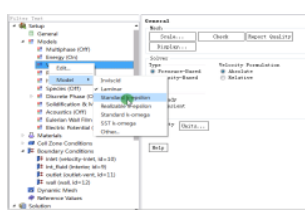

b Turbulence model selection.

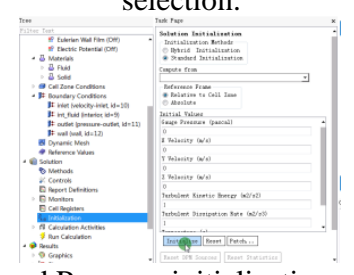

d Program initialization Settings.
Fig . $\mathbf{3}$ simulation parameter settings

Table 1 Physical properties of flue gas.

\begin{tabular}{ccccc}
\hline $\begin{array}{c}\text { Te } \\
\text { mperatu } \\
\text { re }\end{array}$ & $\begin{array}{c}\text { Density } \\
\mathrm{t}\end{array}$ & $\begin{array}{c}\text { Biya heat } \\
\text { capacity }\end{array}$ & $\begin{array}{c}\text { Coefficient of } \\
\text { thermal } \\
\text { conductivity } \lambda\end{array}$ & $\begin{array}{c}\text { Whirlpool } \\
\text { viscosity } \\
\eta\end{array}$ \\
${ }^{\circ} \mathrm{C}$ & $\mathrm{kgm}^{-3}$ & $\mathrm{KJkg}^{-1} k^{-1}$ & $10^{-3} \mathrm{Wm}^{-1} k^{-1}$ & $10^{-3} \mathrm{~kg} /(\mathrm{ms})$ \\
\hline 10 & 1.247 & 1.005 & 2.51 & 1.76 \\
30 & $1 ., 165$ & 1.013 & 2.675 & 1.86 \\
100 & 0.946 & 1.009 & 3.21 & 2.19 \\
160 & 0.815 & 1.017 & 3.64 & 2.45 \\
200 & 0.746 & 1.026 & 3.93 & 2.60 \\
250 & 0.674 & 1.038 & 4.27 & 2.74 \\
300 & 0.615 & 1.047 & 4.6 & 2.97 \\
\hline
\end{tabular}

Table 2 Physical properties of air.

\begin{tabular}{|c|c|c|c|c|}
\hline $\begin{array}{c}\text { Temperature } \\
\mathbf{t}\end{array}$ & $\begin{array}{c}\text { Density } \\
\rho \\
\text { kgm }^{-3}\end{array}$ & $\begin{array}{l}\text { Biya } \\
\text { heat } \\
\text { capaci } \\
\text { ty } \\
\mathrm{KJk}^{-1} h\end{array}$ & $\begin{array}{l}\text { Coefficient } \\
\text { of thermal } \\
\text { conductivit } \\
\text { y } \lambda\end{array}$ & $\begin{array}{c}\text { Whirlpool } \\
\text { viscosity } \\
\eta \\
10^{-3} \mathrm{~kg} \\
/(\mathrm{ms})\end{array}$ \\
\hline 10 & 1.247 & 1.005 & 2.51 & 1.76 \\
\hline 30 & $1 ., 165$ & 1.013 & 2.675 & 1.86 \\
\hline 100 & 0.946 & 1.009 & 3.21 & 2.19 \\
\hline 160 & 0.815 & 1.017 & 3.64 & 2.45 \\
\hline 200 & 0.746 & 1.026 & 3.93 & 2.60 \\
\hline 250 & 0.674 & 1.038 & 4.27 & 2.74 \\
\hline 300 & 0.615 & 1.047 & 4.6 & 2.97 \\
\hline
\end{tabular}

Table 3 Material Parameters Table

\begin{tabular}{|c|c|c|}
\hline material & $1 \mathrm{Cr} 18 \mathrm{Ni9Ti}$ & Q235 \\
\hline name & $\begin{array}{c}\text { Hot blast furnace } \\
\text { exchanger }\end{array}$ & others \\
\hline density $\left(\mathrm{kg} / \mathrm{m}^{3}\right)$ & 7900 & 7860 \\
\hline & $198\left(20^{\circ} \mathrm{C}\right)$ & $212\left(20^{\circ} \mathrm{C}\right)$ \\
\hline $\begin{array}{l}\text { Modulus of } \\
\text { elasticity }\end{array}$ & $194\left(100^{\circ} \mathrm{C}\right)$ & $201\left(200^{\circ} \mathrm{C}\right)$ \\
\hline E (Gpa) & $166\left(500^{\circ} \mathrm{C}\right)$ & $193\left(300^{\circ} \mathrm{C}\right)$ \\
\hline Poisson's ratio $\mu$ & 0.26 & 0.29 \\
\hline \multirow{3}{*}{$\begin{array}{c}\text { Thermal } \\
\text { conductivity } \mathbf{K} \\
\left(\mathbf{W} / \mathbf{m}^{2} \cdot{ }^{\circ} \mathrm{C}\right)\end{array}$} & $16.3\left(100^{\circ} \mathrm{C}\right)$ & $61.1\left(200^{\circ} \mathrm{C}\right)$ \\
\hline & $21.8\left(500^{\circ} \mathrm{C}\right)$ & $55.3\left(300^{\circ} \mathrm{C}\right)$ \\
\hline & $24.7\left(700^{\circ} \mathrm{C}\right)$ & $42.7\left(500^{\circ} \mathrm{C}\right)$ \\
\hline \multirow{3}{*}{$\begin{array}{c}\text { Linear expansion } \\
\text { coefficient } \\
\alpha\left(1 /{ }^{\circ} \mathrm{C}\right)\end{array}$} & $1.66 \mathrm{e}-5\left(100^{\circ} \mathrm{C}\right)$ & $1.255 \mathrm{e}-5\left(200^{\circ} \mathrm{C}\right)$ \\
\hline & $1.79 \mathrm{e}-5\left(500^{\circ} \mathrm{C}\right)$ & $1330 \mathrm{e}-5\left(300^{\circ} \mathrm{C}\right)$ \\
\hline & $1.86 \mathrm{e}-5\left(700^{\circ} \mathrm{C}\right)$ & $1.423 \mathrm{e}-5\left(500^{\circ} \mathrm{C}\right)$ \\
\hline
\end{tabular}

Table 4 technical parameters

\begin{tabular}{lccc}
\hline $\begin{array}{l}\text { Technical } \\
\text { parameters }\end{array}$ & $\begin{array}{l}\text { Low calorific value } \\
\text { of coal }\end{array}$ & Grate area & $\begin{array}{c}\text { Heat transfer } \\
\text { area }\end{array}$ \\
\hline numerical & $5000 \mathrm{kcal} / \mathrm{kg}$ & $1.43 \mathrm{~m}^{2}$ & $66.1 \mathrm{~m}^{2}$ \\
\hline
\end{tabular}

Technical
parameters Blower air volume. Coal supply. Fan air volume.

\begin{tabular}{|c|c|c|}
\hline numerical & $991-1910 \mathrm{~m}^{3} / \mathrm{h}$ & $80-160 \mathrm{~kg} / \mathrm{h} \quad 4840-8900 \mathrm{~m}^{3} / \mathrm{h}$ \\
\hline $\begin{array}{l}\text { Technical } \\
\text { parameters }\end{array}$ & Exhaust heat loss & Heat loss \\
\hline numerical & $34.90 \%$ & $3 \%$ \\
\hline
\end{tabular}

\section{Mathematical model establishment and work parameter solution}

\subsection{The establishment of a mathematical model.}

The fluid flow is governed by the law of physical conservation. When the unit basin is numerically analyzed, it is necessary to satisfy the three basic control equations of mass conservation equation, momentum conservation equation, and energy conservation equation. At the same time, the flow is in a turbulent state, and the fluid should also conform to the turbulent transport equation ${ }^{[6]}$. The first equation of mass for the mass conservation equation is: 


$$
\frac{\partial \rho}{\partial t}+\frac{\partial(\rho \mu)}{\partial x}+\frac{\partial(\rho v)}{\partial y}+\frac{\partial(\rho w)}{\partial z}=0
$$

Where $\rho$ is the density, and $\mathrm{u}, \mathrm{v}, \mathrm{w}$ are the components of the velocity vector $\mathrm{u}$ in the $\mathrm{x}, \mathrm{y}$, and $\mathrm{z}$ directions.

The second equation of fluid conservation equation of momentum is:

$$
\begin{aligned}
& \frac{\partial(\rho u)}{\partial t}+\operatorname{div}(\rho u u)=\operatorname{div}(\mu \operatorname{gradu})-\frac{\partial p}{\partial x}+S_{u} \\
& (2) \\
& \frac{\partial(\rho v)}{\partial t}+\operatorname{div}(\rho v u)=\operatorname{div}(\mu)-\frac{\partial P}{\partial y}+S_{v} \\
& \frac{\partial(\rho w)}{\partial t}+\operatorname{div}(\rho w u)=\operatorname{div}(\mu \operatorname{grad} w)-\frac{\partial P}{\partial z}+S_{w}
\end{aligned}
$$

Where the symbols $S_{u} 、 S_{v}$ and $S_{w}$ are the generalized source terms of the momentum conservation equation, $\mathrm{S}_{\mathrm{u}}=\mathrm{F}_{\mathrm{x}}+\mathrm{s}_{\mathrm{x}}, \mathrm{S}_{\mathrm{v}}=\mathrm{F}_{\mathrm{y}}+\mathrm{s}_{\mathrm{y}}, \mathrm{S}_{\mathrm{w}}=\mathrm{F}_{\mathrm{z}}+\mathrm{s}_{\mathrm{z}}$, Among them, the expressions of $\mathrm{s}_{\mathrm{x}} 、 \mathrm{~s}_{\mathrm{y}}$ 、 and $\mathrm{s}_{\mathrm{z}}$ are as follows:

$S_{x}=\frac{\partial}{\partial x}\left(\mu \frac{\partial u}{\partial x}\right)+\frac{\partial}{\partial y}\left(\mu \frac{\partial v}{\partial x}\right)+\frac{\partial}{\partial z}\left(\mu \frac{\partial w}{\partial x}\right)+\frac{\partial}{\partial x}(\lambda \operatorname{div} u)$

$s_{y}=\frac{\partial}{\partial x}\left(\mu \frac{\partial u}{\partial y}\right)+\frac{\partial}{\partial y}\left(\mu \frac{\partial v}{\partial y}\right)+\frac{\partial}{\partial z}\left(\mu \frac{\partial w}{\partial y}\right)+\frac{\partial}{\partial y}(\lambda \operatorname{divu})$

$S_{z}=\frac{\partial}{\partial x}\left(\mu \frac{\partial u}{\partial z}\right)+\frac{\partial}{\partial y}\left(\mu \frac{\partial v}{\partial z}\right)+\frac{\partial}{\partial z}\left(\mu \frac{\partial w}{\partial z}\right)+\frac{\partial}{\partial z}(\lambda \operatorname{divu})$

The third equation of the fluid energy conservation equation, with the temperature $\mathrm{T}$ as a variable, is as follows:

$$
\frac{\partial(\rho T)}{\partial t}+\operatorname{div}(\rho u T)=\operatorname{div}\left(\frac{k}{c_{p}} \operatorname{grad} T\right)+S_{T}
$$

Where $\rho$ is the density, $c_{p}$ is the specific heat capacity, $\mathrm{T}$ is the temperature, $\mathrm{k}$ is the heat transfer coefficient of the fluid, and $S_{T}$ is the internal heat source of the fluid and the part of the fluid mechanical energy converted into heat due to the viscosity.

The turbulence model used in this paper is the standard $\mathrm{k}-\varepsilon$ model. The turbulent kinetic energy $\mathrm{k}$ and dissipation rate $\varepsilon$ equation of the standard $\mathrm{k}-\varepsilon$ model are as follows:

$$
\begin{gathered}
\rho \frac{d k}{d t}=\frac{\partial}{\partial x_{j}}\left[\left(\mu+\frac{\mu_{t}}{\sigma_{k}}\right) \frac{\partial k}{\partial x_{j}}\right]+G_{k}+G_{b}-\rho \varepsilon-Y_{M} \\
\rho \frac{d \varepsilon}{d t}=\frac{\partial}{\partial x_{j}}\left[\left(\mu+\frac{\mu_{t}}{\sigma_{k}}\right) \frac{\partial \varepsilon}{\partial x_{j}}\right]+C_{1 \varepsilon} \frac{\varepsilon}{k}+\left(G_{k}+C_{3 \varepsilon} G_{b}\right)- \\
C_{2 \varepsilon} \rho \frac{\varepsilon^{2}}{k}
\end{gathered}
$$

Where $G_{k}$ denotes the turbulent kinetic energy due to the mean velocity gradient, $G_{b}$ denotes the turbulent kinetic energy due to the impact of buoyancy, and $Y_{M}$ denotes the effect of the compressible turbulent pulsating expansion on the total dissipation rate. The turbulent viscosity coefficient is determined by the following equation:

$$
\mu_{t}=\rho C_{\mu} \frac{k^{2}}{\varepsilon}
$$

In Fluent, as the default value constants, $\mathrm{C}_{1 \varepsilon}=1.44, \mathrm{C}_{2 \varepsilon}=1.92, \mathrm{C}_{3 \varepsilon}=0.09$ the turbulent Prandtl numbers of the turbulent kinetic energy $\mathrm{k}$ and the dissipation rate $\varepsilon$ are $\sigma_{\mathrm{K}}=1.0$ and $\sigma_{\varepsilon}=1.3$, respectively.

\section{Hot air furnace PID controller settings}

The PID control process in the hot blast stove combustion control system of this article mainly uses the flue gas flow and the air flow as the main control object ${ }^{[7]}$. The flue gas and air flow control valve is controlled through the calculation output of the PID controller integrated in the computer software. The implementing agency rationally configures the control of air and smoke volume. The PID control formula is:

$$
u(t)=K_{p}\left[e(t)+\frac{1}{T_{i}} \int_{0}^{t} e(t) d t+T_{d} \frac{d e(t)}{d t}\right]
$$

Where $K_{p}$ is defined as the proportional partial coefficient, $K_{i}$ is defined as the integral part time constant, and $\mathrm{K}_{\mathrm{t}}$ is defined as the differential partial time constant, $\mathrm{K}_{\mathrm{p}}, \mathrm{K}_{\mathrm{i}}$ and $\mathrm{K}_{\mathrm{t}}$ performance indicators are shown in Table 5 .

Table $5 \mathrm{~K}_{\mathrm{p}}, \mathrm{K}_{\mathrm{i}}, \mathrm{K}_{\mathrm{t}}$ performance indicators.

\begin{tabular}{ccccc}
\hline $\begin{array}{c}\text { parameter } \\
\text { name }\end{array}$ & $\begin{array}{c}\text { Rise } \\
\text { time }\end{array}$ & $\begin{array}{c}\text { Overshoot } \\
\text { amount }\end{array}$ & $\begin{array}{c}\text { Transient } \\
\text { time }\end{array}$ & $\begin{array}{c}\text { Static } \\
\text { error }\end{array}$ \\
\hline$K_{p}$ & falling & rising & $\begin{array}{c}\text { A small } \\
\text { change } \\
\text { rising }\end{array}$ & falling \\
$K_{i}$ & falling & rising & eliminate \\
$K_{t}$ & $\begin{array}{c}\text { small } \\
\text { change }\end{array}$ & falling & falling & $\begin{array}{c}\text { A small } \\
\text { change }\end{array}$ \\
\hline
\end{tabular}

Hot air furnace control system control flow chart shown in Figure 4.

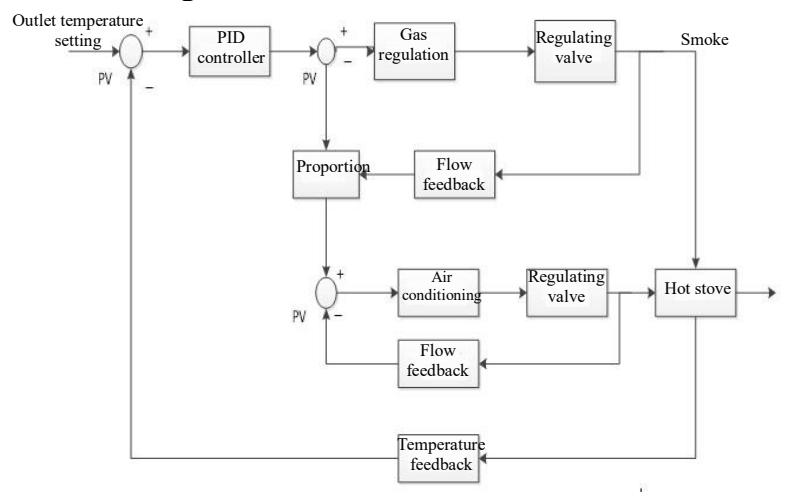

Fig. 4 PID controller schematic

\section{Simulation results and analysis.}

The operating parameters of the hot blast furnace device are mainly the air volume of the blower and the feed amount of the coal. The air volume of the different blowers and the coal feed rate affect the work performance of the hot blast stove. In this paper, the temperature field of the hot blast stove is performed when the air flow of the blower is $900 \mathrm{~m}^{3} / \mathrm{h}, 1200 \mathrm{~m}^{3} / \mathrm{h}$, and $1500 \mathrm{~m}^{3} / \mathrm{h}$ when the 
feed rate of coal is $90 \mathrm{~kg} / \mathrm{h}, 120 \mathrm{~kg} / \mathrm{h}$, and $150 \mathrm{~kg} / \mathrm{h}$, respectively. The analysis of the velocity field and the pressure field is shown in Fig. 5 to Fig. 10.

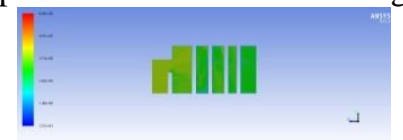

(a) Blower air volume $900 \mathrm{~m}^{3} / \mathrm{h}$

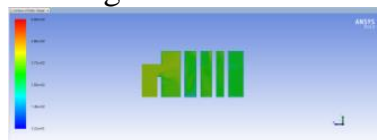

(b) Blower air volume $1200 \mathrm{~m}^{3} / \mathrm{h}$

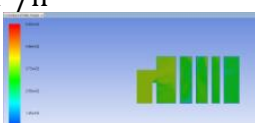

(c) Blower air volume $1500 \mathrm{~m}^{3} / \mathrm{h}$

Fig. 5 Analysis of temperature field of $90 \mathrm{~kg} / \mathrm{h}$ carbon in hot blast stove.

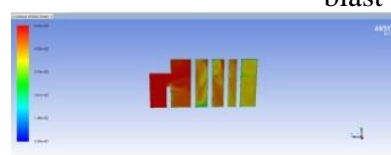

(a) Blower air volume $900 \mathrm{~m}^{3} / \mathrm{h}$

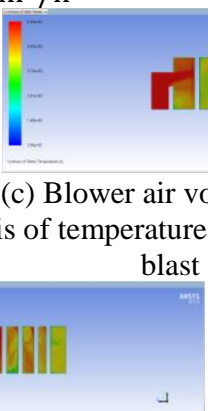
$1200 \mathrm{~m}^{3} / \mathrm{h}$
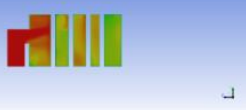
blast stove.

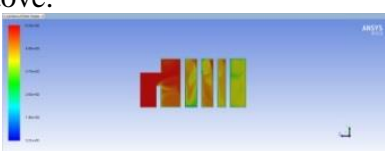

(b) Blower air volume
Fig. 6 Analysis of temperature field of $120 \mathrm{~kg} / \mathrm{h}$ carbon in hot

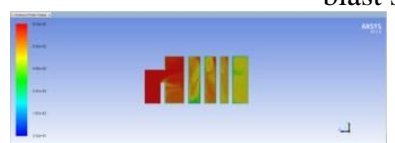

(a) Blower air volume $900 \mathrm{~m}^{3} / \mathrm{h}$

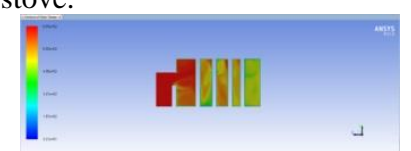

(b) Blower air volume $1200 \mathrm{~m}^{3} / \mathrm{h}$

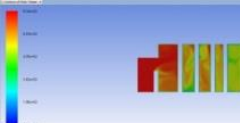

(c) Blower air volume $1500 \mathrm{~m}^{3} / \mathrm{h}$

Fig. 7 Analysis of temperature field of $150 \mathrm{~kg} / \mathrm{h}$ carbon in hot blast stove.

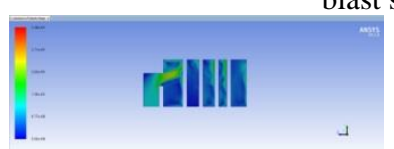

(a) Blower air volume $900 \mathrm{~m}^{3} / \mathrm{h}$

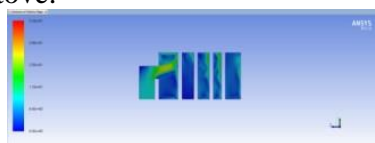

(b) Blower air volume $1200 \mathrm{~m}^{3} / \mathrm{h}$

\section{ज्ञाIII}

(c) Blower air volume $1500 \mathrm{~m}^{3} / \mathrm{h}$

Fig. 8 Analysis of velocity field of $90 \mathrm{~kg} / \mathrm{h}$ carbon in hot blast stove.

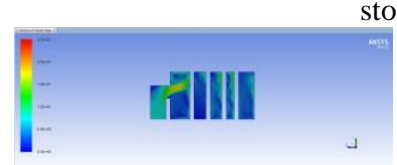

(a) Blower air volume $900 \mathrm{~m}^{3} / \mathrm{h}$

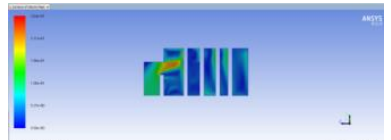

(b) Blower air volume $1200 \mathrm{~m}^{3} / \mathrm{h}$

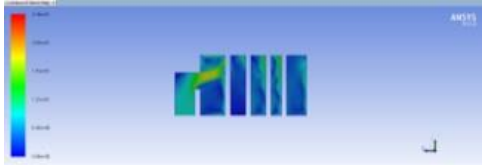

(c) Blower air volume $1500 \mathrm{~m}^{3} / \mathrm{h}$

Fig. 9 Analysis of velocity field of $120 \mathrm{~kg} / \mathrm{h}$ carbon in hot blast stove.

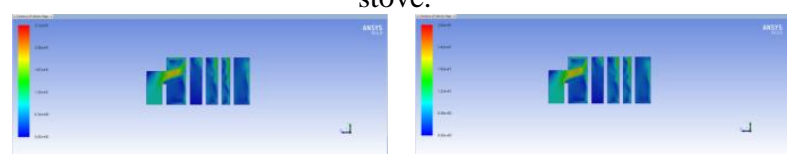

(a) Blower air volume $900 \mathrm{~m}^{3} / \mathrm{h}$

(b) Blower air volume

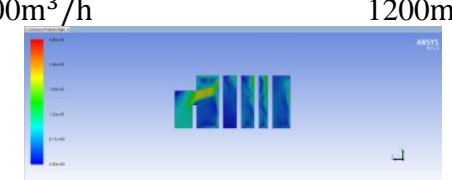

(c) Blower air volume $1500 \mathrm{~m}^{3} / \mathrm{h}$

Fig. 10 Analysis of velocity field of $150 \mathrm{~kg} / \mathrm{h}$ carbon in hot blast stove.

From the temperature field of the hot blast stove shown in Figs. 5-7, the temperature distribution inside the hot blast stove and the amount of blower air are related to the amount of carbon input. When the amount of carbon input is the same, the amount of air entering the hot blast stove is lower when the blower has a lower amount of air. As a result of coal transitional combustion, energy is wasted. When the air volume of a hot blast stove is large, the hot blast furnace enters excess air, resulting in a low outlet temperature of the hot blast furnace. The effect of the temperature distribution of the hot air furnace first increases and then decreases with the increase of the air volume of the blower. As can be seen from the velocity field of the hot blast stove in Figs. 8-10, the velocity field of the hot air is independent of the amount of carbon input, and is related to the air volume of the blower.

From the speed field of the hot blast stove shown in Fig. 8-10, it can be seen that the speed distribution inside the hot blast furnace is better when the amount of carbon in the hot blast stove increases and the air volume of the blower increases. In the hot blast stove, when the carbon input is $90 \mathrm{~kg} / \mathrm{h}$, the air flow of the blower is $900 \mathrm{~m}^{3} / \mathrm{h}$. The speed distribution effect of the hot blast furnace is good. Similarly, when the carbon amount of the hot blast furnace is $120 \mathrm{~kg} / \mathrm{h}$, the air flow of the blower is $1200 \mathrm{~m}^{3} / \mathrm{h}$. The speed distribution effect is good. When the carbon amount in the hot blast furnace is $150 \mathrm{~kg} / \mathrm{h}$, the air flow rate of the blower is $1500 \mathrm{~m}^{3} / \mathrm{h}$. The velocity field distribution of the hot blast furnace is effective. With reference to the temperature field of the hot blast stove of Figs.5-7, it can be seen that when the operating parameters of the hot blast furnace apparatus satisfy the effect of the distribution of the velocity field of the hot blast furnace, the distribution of the temperature field is observed, and the best distribution effect of the temperature field is obtained.

From the analysis of the temperature field and velocity field of the hot blast stove shown in Fig. 5 to Fig. 10, the air volume of the blower of the hot blast furnace varies with the change of the amount of carbon input. In order to ensure better working efficiency, $800 \mathrm{~m}^{3}$ to $1000 \mathrm{~m}^{3}$ air is required per $\mathrm{kg}$ of coal. When the air volume of the 
blower is $1200 \mathrm{~m}^{3} / / \mathrm{h}$ when the carbon amount in the hot blast furnace is $120 \mathrm{~kg} / \mathrm{h}$, the hot blast furnace works well.

\section{Reference}

1. Chen Ming. Numerical simulation of flow field and temperature field of sleeve type hot blast furnace [D]. Northeastern University,2011.

2. Guo Lanlan. Design and implementation of control system of hot air stove [D]. Beijing university of chemical technology,2017.

3. Zhou Handong. Numerical simulation and strength analysis of flow field of sleeve type hot air furnace [D]. Northeastern University,2010.

4. Liang Huanhuan. Optimization design and research on combustion control system of hot air furnace [D]. $\mathrm{Xi}$ 'an university of architecture and technology,2016.

5. Zhou Huigan, Sun Songlin, Siao Mingtao, Cao Lin, He Shao-Ming, Zou Nan. Based on the PID algorithm, the thermal wind temperature control and simulation analysis of hot air stove [J]. Chinese agricultural bulletin,2016,32(15):182-186.

6. Gao Qiang. Experimental study on optimization of biomass hot blast furnace and simulation of heat exchanger temperature field [D]. Harbin Institute of Technology,2016.

7. Liu Piliang, Yang Wei, Cui Guimei. Application of PID parameter self-tuning method in combustion control of hot air furnace $[\mathrm{J}]$. Computer measurement and control,2015,23(03):805-808. 